\title{
Effects of using Inspiration software on Iranian EFL learners' prewriting strategies
}

\author{
Afshari, Somayeh \\ English Department, Faculty of Humanities, Najafabad Branch, Islamic Azad University, Najafabad, Iran \\ (Saminafshary1@yahoo.com) \\ Salehi, Hadi $\bowtie$ \\ English Department, Faculty of Humanities, Najafabad Branch, Islamic Azad University, Najafabad, Iran \\ (hadisalehi1358@yahoo.com)
}

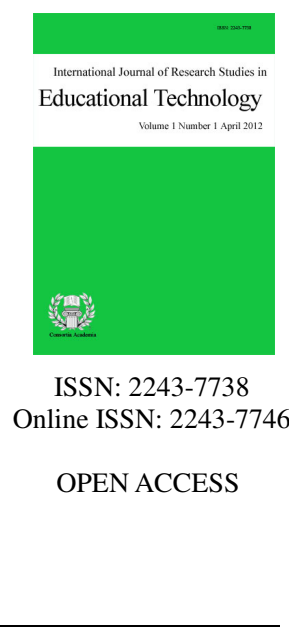

Received: 1 November 2016
Available Online: 29 January 2017

Revised: 11 January 2017

Accepted: 16 January 2017

\section{Abstract}

The motive behind this study was to figure out (a) whether teaching prewriting strategies via the computer software Inspiration 9 could be used as a viable resource to boost EFL learners' command of L2 writing, and (b) whether the targeted L2 learners welcomed the application of this software for the purpose of prewriting strategies instruction. To meet the objectives of the study, 63 intermediate Iranian EFL learners (41 female and 22 male) who were studying English in intact classes at Jahad Daneshgahi, Isfahan, Iran, were conveniently accessed. The learners formed an experimental group, which was taught, through Inspiration 9 software, to use prewriting strategies pertinent to generating ideas through freewriting, brainstorming, listing, clustering, and asking wh-questions during the planning stage of writing, and a control group, in which the learners received the same type of instruction in a traditional classroom setting. Data obtained from writing pretest and posttest scores of the two groups were analyzed through independent-samples $t$ tests, and the results indicated that the experimental groupers significantly outperformed their control group counterparts after the instructional period ended. A researcher-made questionnaire was also handed out to the learners in the experimental group, the results of which, analyzed through one-sample $t$ test, revealed that the EFL learners under investigation held positive attitudes towards the teaching of prewriting strategies via the computer software Inspiration 9. Implications for ELT teachers include, among other things, incorporation of useful technological tools, such as Inspiration 9, in L2 teaching classes.

Keywords: L2 writing; prewriting strategies instruction; CALL; Inspiration 9; attitude 


\section{Effects of using Inspiration software on Iranian EFL learners' prewriting strategies}

\section{Introduction}

Writing is an important productive skill that can be used in learning other receptive and productive skills (Zhu, 2004). Writing encourages thinking and learning, motivates communication, and makes thought available for reflection (Mekheimer, 2005). When thought is written down, ideas can be examined, reconsidered, superseded, rearranged, and changed. The paramount importance of this indispensable skill is further stated by Olshtain (2001) "...the skill of writing enjoys special status-it is via writing that a person can communicate a variety of messages to close or distant known or unknown readers" (p. 207).

In spite of its importance, students of writing, and their teachers, too, experience a variety of unfavorable emotions, ranging from fear, to trepidation to elation (Arnold, 2007; Byrd, 2010; Zhu, 2004) which potentially hinder the development of their writing skills. This is the case probably because writing, be it in one's first or second language, is one of the most demanding skills that our students have to learn (Rivers, 1981). The onerous nature of writing has recurrently been acknowledged by experts in the field. For instance, Nunan (1989) maintains "it has been argued that learning to write frequently and expressively is the most difficult of the motor skills for all language users regardless of whether the language in question is a first, second or foreign language" (p. 35). Later, Nunan (1999) contends that "...producing a coherent, fluent, extended piece of writing is probably the most difficult thing there is to do in language" (p. 271). Richards and Renandya (2002) take a more unwavering stance in this regard and hold that "there is no doubt that writing is the most difficult skill for L2 learners to master" (p. 271).

Although applied linguists have come to recognize the importance of writing in its own right as well as its complexity, writing remains one of the least well-understood subjects in applied linguistics (Silva \& Matsuda, 2002). Richards (1990) also expresses the same idea through the following sentence, "The nature and significance of writing has traditionally been underestimated in language teaching" (p. 106). The teaching of this demanding skill experienced a shift from the product-oriented approach to the process-oriented approach. In the writing process, there are the three stages of planning, drafting, and revising. In the planning stage, to help EFL learners generate ideas, instructors could teach them to use prewriting strategies.

\section{Review of the literature}

Owing to the fact that there is an urgent need to communicate via computers in the world of globalization, research on second language writing has been gathering unprecedented momentum. Second language writing scholarship, according to Silva and Brice (2004) has increased its breadth and depth and has become a legitimate area of investigation in its own right. Suffice it to mention that it includes, though is not limited to, the enquiry in the following areas: research on composing processes, assessment of writing, content-based writing instruction, voice and identity in writing, reading-writing connection, computer-based writing pedagogy, linguistic accuracy in writing, peer interaction, teacher feedback, plagiarism, curricular issues pertinent to writing programs, and ideological matters germane to writing.

Since the focus of the present study is on prewriting strategies (which are among the sub-processes of writing) and technology-supported writing, a very short reference is made here to the literature related to these issues. Research on the use of computer-assisted language learning (CALL) in different situations has been in place for decades. Many researchers hold that it has enormous potentials for the future development of second language teaching and learning (Ayres, 2002; Chikamatsu, 2003). CALL has offered worthwhile possibilities in the virtual environment for foreign language teaching and learning.

One of the aspects reflected in the current research is the shift from the traditional product-oriented writing 
methodology to writing as a process that emphasizes learner-centeredness. Since the latter promotes learner variables such as language learning strategies, prewriting strategies are chosen to be investigated in this study. The incentive to choose prewriting strategies derives from the claims of such scholar as Polio and Williams (2009) who contend that "[p]re-writing is an essential component of a process approach...but surprisingly little research has examined prewriting techniques." The current study, therefore, aimed at carrying out research on prewriting strategies, and sought to explore the effectiveness of inspiration software in this regard. Moreover, exploring the attitudes of the learners towards the instruction of prewriting strategies via this software was another aim of this study. That is why the present study embarked on an investigation to find answers to the following research questions:

$>$ Research Question 1: Does teaching of prewriting strategies via Inspiration 9 software lead to an improvement in EFL learners' writing ability?

$>\quad$ Research Question 2: How do Iranian EFL learners perceive the application of Inspiration in order to teach prewriting strategies?

\section{Methodology}

This study sought to (a) find out whether teaching prewriting strategies with Inspiration 9 software could help EFL learners to improve their writing performance or not, and (b) see whether Iranian EFL learners held positive attitudes towards inspiration-based teaching of prewriting strategies or not.

\subsection{Participants}

To choose the participants for this study, a number of accessible intermediate EFL learners in two intact language learning classes were used. One of the classes was randomly labeled control group (CG) and the other class was chosen to be the experimental group (EG). The learners were selected from among intermediate Iranian EFL learners who were studying English at Jahade-Daneshgahi Institute in Isfahan, Iran. They were male and female learners with the same native language (i.e. Persian), and roughly the same age range (18 to 29), who were accessed through convenience sampling method.

\subsection{Materials and Instruments}

In the present study, the instructional materials included the materials to teach prewriting strategies; they were collected from several writing books such as Writing Power, Refining Composition Skills, and Writing in Paragraphs. Three instruments were used in this study: a writing pretest, a writing posttest, and an attitude questionnaire. The writing pretest was used to make certain the students in the two groups were homogeneous. The learners were asked to complete the writing task within 45 minutes. The writing posttest was also constructed and implemented in the same way, i.e. it contained an argumentative prompt and it was administered in a 45-minute time limit. The writing pretest and posttest were rated based on Weir's (1990) scoring scale. This scoring scale tested the learners' writing with respect to (a) relevance and adequacy of content, (b) compositional organization, (c) cohesion, (d) adequacy of vocabulary for purpose, (e) grammar, (f) punctuation, and (g) spelling. Based on this scale, the learners' scores ranged between 7 and 28. An attitude questionnaire, which took into consideration the learners' attitudes towards the different aspects of computer-based teaching of prewriting strategies, was developed by the researcher and used to answer the second research question of the study. This questionnaire consisted of 15 Likert-scale items, each with five alternatives ranging from strongly agree, through agree, uncertain, disagree, to strongly disagree. The reliability of the questionnaire was checked by means of Cronbach's alpha formula (0.78) and its validity was assured by a panel of experts.

\subsection{Procedures}

To conduct this research, the following steps were taken: At first, one group was randomly chosen as the 
Afshari, S., \& Salehi, H.

experimental group (EG) and the other served as the control group (CG). Then a writing pretest was administered to make sure the learners in the two groups were homogeneous. Using the software Inspiration 9, the strategies of brainstorming, free writing, clustering, listing and asking wh-questions were taught to the learners in the experimental group as part of their class practices. Those in the control group also received the same materials, though through a traditional face-to-face classroom environment. The learners in both groups were asked to take a writing posttest. The scores the learners obtained on the posttest enabled the researcher to make conclusions about the effectiveness of traditional and computer-based teaching of prewriting strategies. Finally, the learners in the experimental group were asked to fill out a questionnaire seeking to explore their attitudes towards computer-based teaching of prewriting strategies.

\section{Data analysis and results}

Independent-Samples $t$ test was applied twice: once to compare the pretest scores of the participants in the groups to make certain they were equal before beginning the experiment beginning, and once after the completion of the experiment to see whether the treatment were effective or not. The data obtained from the questionnaire were analyzed using such descriptive statistics as frequency counts, percentages, and mean scores. Also, one-sample $t$ test was employed to analyze the data elicited through the questionnaire.

As it can be seen in Table 1, in terms of relevance and adequacy of content, the EG learners $(M=1.96)$ and their CG counterparts $(M=1.80)$ were not found to be significantly different since the $p$ value under the Sig. (2-tailed) column corresponding to this comparison was larger than the significance level $(.40>.05)$. The same result was obtained for compositional organization $\left(M_{\mathrm{EG}}=1.57, M_{\mathrm{CG}}=1.67, p=46\right)$, cohesion $\left(M_{\mathrm{EG}}=1.67, M_{\mathrm{CG}}\right.$ $=1.58, p=54)$, adequacy of vocabulary for purpose $\left(M_{\mathrm{EG}}=2.17, M_{\mathrm{CG}}=1.96, p=36\right)$, grammar $\left(M_{\mathrm{EG}}=2.50\right.$, $\left.M_{\mathrm{CG}}=2.45, p=81\right)$, punctuation $\left(M_{\mathrm{EG}}=2.21, M_{\mathrm{CG}}=2.03, p=35\right)$, and spelling $\left(M_{\mathrm{EG}}=2.89, M_{\mathrm{CG}}=2.51, p=\right.$ $09)$. Finally, the difference between the total writing scores of EG $(M=15.00)$ and those of CG $(M=14.03)$ did not reach statistical significance owing to the fact that the relevant $p$ value was found to be greater than the significance level $(.08>.05)$.

\section{Table 1}

Results of Independent-Samples t Test Comparing EG and CG Learners' Writing Pretest

\begin{tabular}{|c|c|c|c|c|c|c|c|}
\hline & & $N$ & Mean & $S D$ & $t$ & $d f$ & Sig. (2-tailed) \\
\hline $\begin{array}{l}\text { Relevance and } \\
\text { adequacy of } \\
\text { content }\end{array}$ & $\begin{array}{l}\text { EG } \\
\text { CG }\end{array}$ & $\begin{array}{l}28 \\
31\end{array}$ & $\begin{array}{l}1.96 \\
1.80\end{array}$ & $\begin{array}{l}.69 \\
.74\end{array}$ & .83 & 57 & .40 \\
\hline $\begin{array}{l}\text { Compositional } \\
\text { organization }\end{array}$ & $\begin{array}{l}\text { EG } \\
\text { CG }\end{array}$ & $\begin{array}{l}28 \\
31\end{array}$ & $\begin{array}{l}1.57 \\
1.67\end{array}$ & $\begin{array}{l}.57 \\
.54\end{array}$ & -.73 & 57 & .46 \\
\hline Cohesion & $\begin{array}{l}\text { EG } \\
\text { CG }\end{array}$ & $\begin{array}{r}28 \\
31 \\
\end{array}$ & $\begin{array}{l}1.67 \\
1.58 \\
\end{array}$ & $\begin{array}{l}.61 \\
.62 \\
\end{array}$ & .60 & 57 & .54 \\
\hline $\begin{array}{l}\text { Adequacy of } \\
\text { vocabulary for } \\
\text { purpose }\end{array}$ & $\begin{array}{l}\text { EG } \\
\text { CG }\end{array}$ & $\begin{array}{l}28 \\
31\end{array}$ & $\begin{array}{l}2.17 \\
1.96\end{array}$ & $\begin{array}{l}.94 \\
.83\end{array}$ & .90 & 57 & .36 \\
\hline Grammar & $\begin{array}{l}\text { EG } \\
\text { CG }\end{array}$ & $\begin{array}{l}28 \\
31\end{array}$ & $\begin{array}{l}2.50 \\
2.45\end{array}$ & $\begin{array}{l}.69 \\
.85 \\
\end{array}$ & .23 & 57 & .81 \\
\hline Punctuation & $\begin{array}{l}\text { EG } \\
\text { CG }\end{array}$ & $\begin{array}{l}28 \\
31\end{array}$ & $\begin{array}{l}2.21 \\
2.03\end{array}$ & $\begin{array}{l}.78 \\
.70\end{array}$ & .93 & 57 & .35 \\
\hline Spelling & $\begin{array}{l}\text { EG } \\
\text { CG }\end{array}$ & $\begin{array}{l}28 \\
31\end{array}$ & $\begin{array}{l}2.89 \\
2.51\end{array}$ & $\begin{array}{l}.83 \\
.88 \\
\end{array}$ & 1.67 & 57 & .09 \\
\hline $\begin{array}{r}\begin{array}{r}\text { Total writing } \\
\text { score }\end{array}\end{array}$ & $\begin{array}{l}\text { EG } \\
\text { CG }\end{array}$ & $\begin{array}{l}28 \\
31\end{array}$ & $\begin{array}{l}15.00 \\
14.03\end{array}$ & $\begin{array}{l}1.72 \\
2.44\end{array}$ & 1.74 & 57 & .08 \\
\hline
\end{tabular}


The conclusion to be drawn from these analyses would be that the EG and CG were approximately equal in terms of their overall writing ability (which comprised adequacy of content, compositional organization, cohesion, adequacy of vocabulary for purpose, grammar, punctuation, and spelling). This parity between the two groups at the outset of the study enabled the researcher to attribute the putative subsequent differences between the two groups to the instruction to which they were exposed. Figure 1 also shows the rough equality of the two groups in relation to the different components of writing ability.

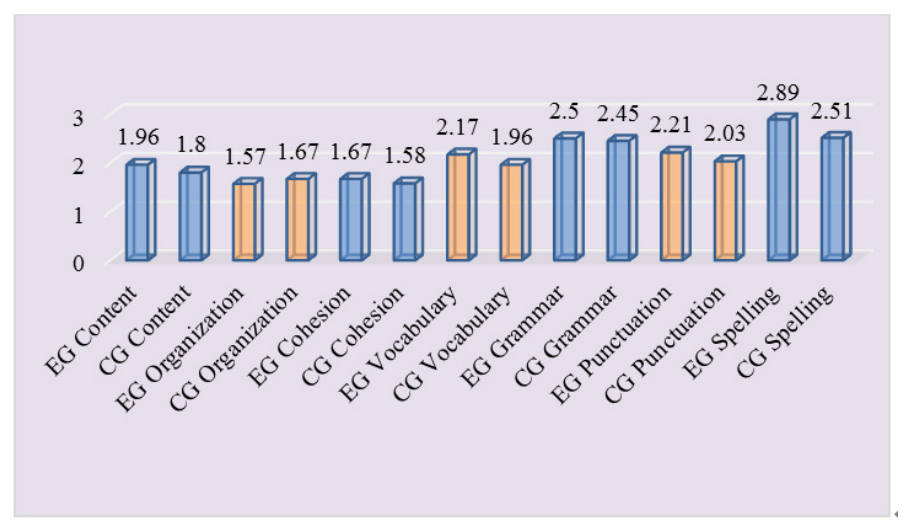

Figure 1. EG and CG Learners' Pretest Mean Scores for Different Components of Writing

It could be easily seen in Figure 1 that on the pretest, the two groups were almost equal with respect to relevance and adequacy of content, compositional organization, cohesion, adequacy of vocabulary for purpose, grammar, punctuation, and spelling.

Table 2

Results of Independent-Samples t Test Comparing EG and CG Learners' Writing Posttest Scores

\begin{tabular}{|c|c|c|c|c|c|c|c|}
\hline & & $N$ & Mean & $S D$ & $t$ & $d f$ & Sig. (2-tailed) \\
\hline $\begin{array}{l}\text { Relevance and } \\
\text { adequacy of } \\
\text { content }\end{array}$ & $\begin{array}{l}\mathrm{EG} \\
\mathrm{CG}\end{array}$ & $\begin{array}{l}28 \\
31\end{array}$ & $\begin{array}{l}3.39 \\
2.22\end{array}$ & $\begin{array}{l}.56 \\
.56\end{array}$ & 7.94 & 57 & .000 \\
\hline $\begin{array}{l}\text { Compositional } \\
\text { organization }\end{array}$ & $\begin{array}{l}\mathrm{EG} \\
\mathrm{CG}\end{array}$ & $\begin{array}{l}28 \\
31 \\
\end{array}$ & $\begin{array}{l}3.07 \\
1.87 \\
\end{array}$ & $\begin{array}{l}.26 \\
.42 \\
\end{array}$ & 12.83 & 57 & .000 \\
\hline Cohesion & $\begin{array}{l}\mathrm{EG} \\
\mathrm{CG}\end{array}$ & $\begin{array}{l}28 \\
31\end{array}$ & $\begin{array}{l}2.25 \\
2.12\end{array}$ & $\begin{array}{l}.44 \\
.67\end{array}$ & .80 & 57 & .42 \\
\hline $\begin{array}{l}\text { Adequacy of } \\
\text { vocabulary for } \\
\text { purpose }\end{array}$ & $\begin{array}{l}\mathrm{EG} \\
\mathrm{CG}\end{array}$ & $\begin{array}{l}28 \\
31\end{array}$ & $\begin{array}{l}3.17 \\
2.25\end{array}$ & $\begin{array}{l}.66 \\
.81\end{array}$ & 4.70 & 57 & .000 \\
\hline Grammar & $\begin{array}{l}\mathrm{EG} \\
\mathrm{CG}\end{array}$ & $\begin{array}{l}28 \\
31 \\
\end{array}$ & $\begin{array}{l}2.82 \\
2.93 \\
\end{array}$ & $\begin{array}{l}.66 \\
.57 \\
\end{array}$ & -.70 & 57 & .48 \\
\hline Punctuation & $\begin{array}{l}\mathrm{EG} \\
\mathrm{CG}\end{array}$ & $\begin{array}{l}28 \\
31 \\
\end{array}$ & $\begin{array}{l}2.60 \\
2.48 \\
\end{array}$ & $\begin{array}{l}.56 \\
.50 \\
\end{array}$ & .88 & 57 & .38 \\
\hline Spelling & $\begin{array}{l}\mathrm{EG} \\
\mathrm{CG}\end{array}$ & $\begin{array}{l}28 \\
31 \\
\end{array}$ & $\begin{array}{l}3.25 \\
2.74 \\
\end{array}$ & $\begin{array}{l}.64 \\
.68 \\
\end{array}$ & 2.93 & 57 & .005 \\
\hline $\begin{array}{r}\text { Total writing } \\
\text { score }\end{array}$ & $\begin{array}{l}\mathrm{EG} \\
\mathrm{CG}\end{array}$ & $\begin{array}{l}28 \\
31\end{array}$ & $\begin{array}{l}20.57 \\
16.64\end{array}$ & $\begin{array}{l}1.25 \\
1.40\end{array}$ & 11.26 & 57 & .000 \\
\hline
\end{tabular}

As could be seen in Table 2, the differences between the EG and CG learners regarding relevance and adequacy of content $(p=.000)$, compositional organization $(p=.000)$, adequacy of vocabulary for purpose ( $p$ $=.000)$, and spelling $(p=.005)$ reached statistical significance, but these two groups were not found to be 
Afshari, S., \& Salehi, H.

significantly different with respect to cohesion $(p=.42)$, grammar $(p=.48)$, and punctuation $(p=.38)$. All this boiled down to the conclusion that at the end of the experiment, the EG learners could significantly outperform their EG counterparts since the total writing scores of the two groups turned out to be significantly different $\left(M_{\mathrm{EG}}=20.57, M_{\mathrm{CG}}=16.64, p=46\right)$.

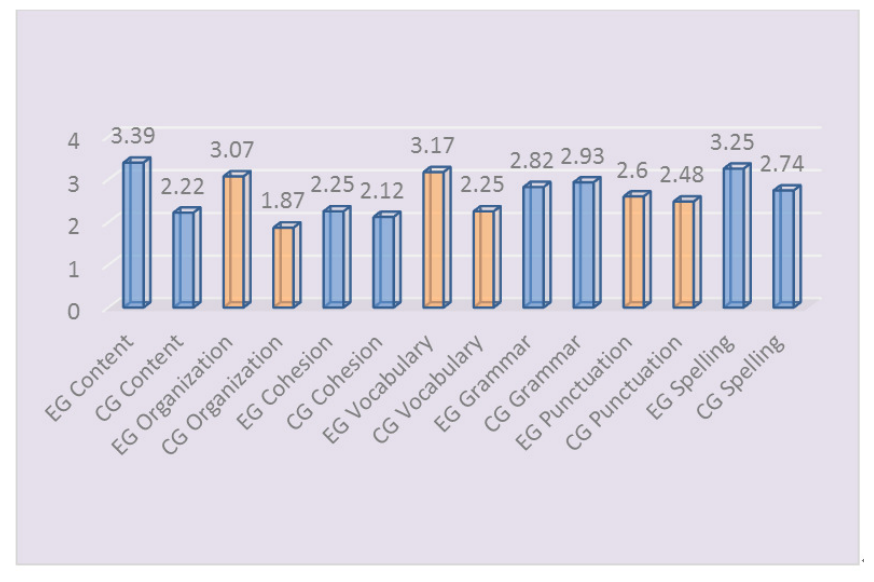

Figure 2. EG and CG Learners' Posttest Mean Scores for Different Components of Writing

Evident in Figure 2 are the results showing that the EG and CG learners were significantly different with reference to relevance and adequacy of content, compositional organization, adequacy of vocabulary for purpose, and spelling. They were, however, not considerably different regarding their cohesion, grammar, and punctuation scores. Figure 2 also revealed the significant difference between the two groups' overall writing ability on the posttest.

As for the attitudes of the EG learners towards the treatments they received, the questionnaire results revealed that the learners' agreed with all the questionnaire items (to be found in the Appendix), which referred to the positive impacts of using Inspiration 9 software in L2 writing classes. As mentioned above, one-sample $t$ test was used to see if the mean scores of the questionnaire items were significantly higher than the average value of the choices (i.e. 3.00) with $\mathrm{t}=28.31(p=.000, \mathrm{df}=14$, mean difference $=1.38)$. Results show that there was a statistically significant difference between the EG learners' mean attitude score $(M=4.38)$ and the average value of the choices (i.e. 3.00) due to the fact that the $p$ value was smaller than the specified level of significance $(.000<.05)$. It could be thus concluded that using Inspiration 9 to teach prewriting strategies was approved of by the EG learners and they were pleased about it.

\section{Discussion}

The results obtained for each research question are discussed in light of the past studies in the literature and concluding remarks are made in what follows:

\subsection{Research Question One}

By comparing the findings of the first research question of the two groups, it was found that EG learners (who were exposed to computer-based teaching of prewriting strategies) were found to significantly excel the EG learners regarding a) relevance and adequacy of content, b) compositional organization, c) adequacy of vocabulary for purpose, and d) spelling on the posttest. The two groups, nonetheless, remained roughly equal regarding their cohesion, grammar, and punctuation scores. Above all, there was a statistically significant difference between the two groups' overall writing ability on the posttest, which indicated the effectiveness of computer-based teaching of prewriting strategies. It can be construed from the results of this study that the teaching of the intended prewriting strategies via Inspiration 9 did have a positive effect on the writing ability of 
the participants. This finding seems to endorse the findings of the studies which give credit to the usefulness of writing strategies (Leki, 1995; Lv \& Chen, 2010; Matsunomo, 1995; McMullen, 2009; Riazi, 1997), brainstorming (Horung, 2000), and idea generation (Lally, 2000; Shafiee, Koosha, \& Afghari, 2015). This finding, moreover, lends support to those of Cumming (1989) and Roca de Larios, Murphy, and Martin (2001) in that student can be trained to draw upon planning strategies.

As Chamot (2005) maintains, writing in a new language is arguably the most demanding of the modalities in which one can achieve communicative competence. Novice writers struggle with finding the words they need and remembering grammatical structures, whereas more advanced students find it difficult to link their ideas with coherence and to produce appropriate target language discourse. Given these difficulties, instruction in writing strategies could be beneficial for L2 learners. That is why (computer-based prewriting strategies) instruction in the present study was found to positively and significantly affect Iranian EFL learners' L2 writing.

\subsection{Research Question Two}

The second research question of the study and its results made it clear that the learners under investigation in the present study held positive attitudes towards the use of Inspiration 9 software program in EFL writing classes. As a matter of fact, a small number of EFL/ESL research findings have shown that the use of CALL may not yield positive effects due to various reasons like dearth of technical knowledge or other adaption problems encountered by second language learners (Nutta, Feyton, Norwood, Meros, Yoshil, \& Ducher, 2002; Smith \& Woody, 2000), but most of the research findings have confirmed that the positive effects always outweigh the negative effects and that positive attitudes have always been obtained in the wake of a CALL treatment. Klassen and Milton (1999), for instance, evaluated the effectiveness of a multimedia-based learning program and they could observe positive attitudinal changes for the multimedia used, as well as enhanced learning outcomes. This could probably be attributed to the absorbing learning environment of the computer-based programs, compared to the traditional face-to-face classes, where the commonplace, hackneyed routines are likely to bore learners.

\section{Conclusions and implications}

Previous research has paid comparatively scant attention to the investigation of the effects of prewriting strategies on EFL learners' writing ability. Little comparative research has also examined the promising prospects of instruction through computer software programs such as Inspiration 9. This study, accordingly, took these issues into consideration and employed a quasi-experimental design to unearth the effects of teaching prewriting strategies through Inspiration 9 on writing ability of Iranian EFL learners. The results of the study demonstrated the remarkable effects of this type of instruction on EFL students' writing ability. Moreover, teaching prewriting strategies in this fashion was proved to be welcomed by the learners exposed to it.

What sets the current study apart from the previous studies in this domain (and thus features as the contribution of this study to the field of computer-enhanced teaching of writing/prewriting instruction) is the fact that an atomistic approach was adopted to analyze the writing performance of the learners, and it was shown that using Inspiration 9 helped learners improve in some aspects of writing (relevance and adequacy of content, compositional organization, adequacy of vocabulary for purpose, and spelling) but not in others (cohesion, grammar, and punctuation).

Based on the findings of this study, it is suggested that a thoroughly informed instruction of prewriting strategies be incorporated in EFL writing classes. Before the commencement of instruction, teachers are recommended to figure out what strategies their students already possess, and then cater the type of instruction that includes a range of useful prewriting strategies which their students should know and utilize. The thoroughly informed instruction in itself can teach students how and why to use, transfer, and evaluate the learned strategies (Oxford \& Crookall, 1989). 
Foreign language writing teachers usually tend to draw their students' attention more on the drafting and revision stages of the writing process, and provide teacher and/or peer feedback on the students' written productions. In practice, prewriting strategies are rarely dealt with in class, insufficient time is allotted to them, and their applications are sometimes not explicitly delineated by the instructors. This brings about a situation where students have freedom to plan or not to plan before writing, and some (if not most or even all) of them may prefer not to, and proceed directly to the drafting stage of writing, particularly those who compose via computers (Haas, 1989). What should be borne in mind is to put emphasis on the planning stage by teaching language learners how to plan for their writing and by allotting ample planning time for their writing process in case they write in class or by encouraging students to spend time planning when they write at home. This planning time might take longer for some students at the beginning of their writing instruction, but when students practice doing it more often, they might be able to plan within a shorter period of time.

Once learners are convinced to look before they jump (i.e. to plan before they write), they could be given the opportunity to take full advantage of the computer technology. In fact, these days there are a host of offline and online tools such as a variety of software programs and websites dedicated to the teaching of different aspects of language. It is suggested that EFL teachers get familiar with these opportunities and talk their learners into using them by demonstrating the effectiveness of using such facilities. Finally, textbook writers and materials developers who compile EFL writing books are also recommended to take advantage of online and offline technological tools which can aid the teaching of prewriting strategies in their instructional materials.

In this study, the effect of teaching prewriting strategies the software Inspiration 9, and the learners' attitudes towards this treatment were investigated. A number of potential threats to external and internal validity could be enumerated for this study. Before listing these threats, it seems necessary to mention what Pederson (1987, as cited in Chapelle, 2010) argues regarding generalizability of findings obtained from computer-assisted language instruction. She believes that comparative research on computer-assisted versus non-computer-assisted language instruction is incapable of providing generalizable results due to three reasons: the impossibility of exact replication, the uncertainty about the causes of outcomes, and the lack of connection of such research with language learning theory. Chapelle (2010) adds a fourth reason to the previous reasons and contends that technology is often used to change and expand the intended learning outcomes rather than to increase the level of performance in exactly the same areas as those targeted by classroom instruction. Apart from these considerations, the following limitations, which more specifically pertain to the findings of the present study, are mentioned here. First, as regards sampling procedure, the study utilized a convenience (alternatively called availability) sampling, thereby choosing subjects available at Jahade-Daneshgahi language institute in Isfahan; hence, the findings might not be generalizable to other EFL populations. Second, there was the problem of inability to embrace all the learner variables (e.g. motivation, learning style, personality type, gender, etc.) affecting students' performance. Furthermore, social aspects, such as student interaction and collaboration, were not included and investigated in the study.

Owing to the fact that L2 prewriting strategies instruction is an underexplored area, a good number of studies in the future can examine different aspects of this subject. Very simply, a replication study could investigate the effects of teaching prewriting strategies via the same of even a different software program on different aspects of writing such as content, organization, diction, unity, etc. Further, in the design of the study, a delayed posttest could be added in order to examine the computer-enhanced training effects of prewriting strategies on writing in the long run. Third, other methods of input delivery than those utilized in this study could be employed to see if they have differential effects on the students' writing ability or not. To be more precise, other computerized learning tools such as idea generation/organization software not incorporated in this study could be used, and their effects on the learners' writing could be compared and evaluated. In addition, researchers could draw upon social constructivist frameworks, build online learning communities, and study how efficacious these online learning communities could be compared to traditional learning classrooms. Finally, in a study similar to the present research, a variety of other prewriting strategies, such as forming discussion groups or doing online reading before writing, can be used to explore their possible effects on writing skills of EFL 
learners.

\section{References}

Arnold, N. (2007). Reducing foreign language communication apprehension with computer-mediated communication: A preliminary study. System, 35, 469-486. https://doi.org/10.1016/j.system.2007.07.002

Ayres, R. (2002). Learner attitudes towards the use of CALL. Computer Assisted Language Learning, 15(3), 241-249. https://doi.org/10.1076/call.15.3.241.8189

Byrad, D. (2010). Framing, reflecting on and attending to a rationale of teaching of writing in the second language classroom via journaling: A case study. System, 38, 200-210. https://doi.org/10.1016/j.system.2010.03.002

Chamot, A. U. (2005). The cognitive academic language learning approach (CALLA): An update. In P. A. Richard-Amato \& M. A. Snow (Eds.), Academic success for English language learners: Strategies for K-12 mainstream teachers (pp. 87-101). White Plains, NY: Longman.

Chapelle, C. A. (2010). The spread of computer-assisted language learning. Language Technology, 43(1), 66-74. https://doi.org/10.1017/S0261444809005850

Chikamatsu, N. (2003). The effect of computer on L2 Japanese writing. Foreign Language Annuals, 36(1), 114-127. https://doi.org/10.1111/j.1944-9720.2003.tb01937.x

Cumming, A. (1989). Writing expertise and second language proficiency. Language Learning, 39, 81-141. https://doi.org/10.1111/j.1467-1770.1989.tb00592.x

Haas, C. (1989). How the writing medium shapes the writing process: Effects of word processing on planning. Research in the Teaching of English, 23, 181-207.

Hornung, A. (2000). Method awareness and the teaching of writing. In G. Brauer (Ed.), Writing across languages (pp. 131-140). Stamford, CT: Ablex.

Klassen J., \& Milton, P. (1999). Exchanging English language skills using multimedia: Tried and tested. Computer Assisted Language Learning, 12(4), 281-294. https://doi.org/10.1076/call.12.4.281.5706

Lally, C. G. (2000). First language influences in second language composition: The effect of pre-writing. Foreign Language Annals, 33(4), 428-432. https://doi.org/10.1111/j.1944-9720.2000.tb00623.x

Leki, I. (1995). Coping strategies of ESL Students in writing tasks across the curriculum. TESOL Quarterly, 29(2), 235-260. https://doi.org/10.2307/3587624

Lv, F., \& Chen, H. (2010). A study of metacognitive-strategies-based writing instruction for vocational college students. English Language Teaching, 3(3), 136-144. https://doi.org/10.5539/elt.v3n3p136

Matsumoto, K. (1995). Research paper writing strategies of professional Japanese EFL writers. TESL Canada Journal, 13(1), 17-27. https://doi.org/10.18806/tesl.v13i1.658

McMullen, M. G. (2009). Using language learning strategies to improve the writing skills of Saudi EFL students: Will it really work? System, 37, 418-433. https://doi.org/10.1016/j.system.2009.05.001

Mekheimer, M. (2005). Effects of Internet-based Instruction, Using Webquesting and emailing on developing some essay writing skills in student teachers (Unpublished doctoral dissertation). Cairo University.

Nunan, D. (1989). Designing tasks for the communicative classroom. Cambridge: Cambridge University Press.

Nunan, D. (1999). Learner strategy training in the classroom: An action research. TESOL Journal, 6(1), 35-41.

Nutta, J., Feyton, C., Norwood, A., Meros, J., Yoshil, M., \& Ducher, J. (2002). Exploring new frontiers: What do computers contribute to teaching foreign language in elementary schools? Foreign Language Annuals, 35(3), 239-306. https://doi.org/10.1111/j.1944-9720.2002.tb01855.x

Olshtain, E. (2001). Functional tasks for mastering the mechanics of writing and going just beyond. In M. Celce-Murcia (ed.), Teaching English as a second or foreign language (pp. 207-217). Boston, MA: Heinle \& Heinle.

Oxford, R., \& Crookall, D. (1989). Language learning strategies, the communicative approach and their classroom implications. Foreign Language Annals, 22(1), 29-39. https://doi.org/10.1111/j.1944-9720.1989.tb03139.x 
Afshari, S., \& Salehi, H.

Polio, C., \& Williams, J. (2009). Teaching and testing writing. In M. H. Long \& C. J. Doughty (Eds.), The handbook of language teaching (pp. 486-517). Malden, MA: Blackwell Publishing. https://doi.org/10.1002/9781444315783.ch26

Riazi, A. (1997). Acquiring disciplinary literacy: A social-cognitive analysis of text production and learning among Iranian graduate students of education. Journal of Second Language Writing, 6(2), 105-137. https://doi.org/10.1016/S1060-3743(97)90030-8

Richards, J. C., \& Renandya, W. A. (2002). Methodology in language teaching: An anthology of current practice. Cambridge: Cambridge University Press. https://doi.org/10.1017/CBO9780511667190

Richards, J. C. (1990). The language teaching matrix. Cambridge: Cambridge University Press. https://doi.org/10.1017/CBO9780511667152

Rivers, W. M. (1981). Teaching foreign language skills ( $2^{\text {nd }}$ ed.). Chicago: The University of Chicago Press.

Roca de Larios, J., Murphy, L., \& Marin, J. (2001). Critical examination of L2 writing process research. In S. Ransdell \& M. L. Barbiere (Eds.), New Directions for Research in L2 Writing (pp. 11-47). Dordrecht: Kluwer Academic Publishers.

Shafiee, S., Koosha, M., \& Afghari, A. (2015). CALL, prewriting strategies, and EFL writing quantity. English Language Teaching, 8(2), 170-177. https://doi.org/10.5539/elt.v8n2p170

Silva, T., \& Brice, C (2004). Research in teaching writing. Annual Review of Applied Linguistics, 24, 70-106. https://doi.org/10.1017/s0267190504000042

Silva, T., \& Matsuda, P. K. (2002). Writing. In N. Schmitt (Ed.), An introduction to applied linguistics (pp. 251-266). New York, NY: Arnold Publishers.

Zhu, W. (2004). Faculty views on the importance of writing, nature of academic writing, and teaching and responding to writing in disciplines. Journal of Second Language Writing, 13, 29-48. https://doi.org/10.1016/j.jslw.2004.04.004 
Appendix

\section{Attitude Questionnaire}

Name:

General Instructions: The purpose of this questionnaire is to examine your attitude toward the application of computer software (Inspiration) in English writing lessons. Please indicate your reaction to each of the following statements by circling the number that represents your level of agreement or disagreement with it. Make sure to respond to every statement.

Thank you!

\begin{tabular}{|c|c|c|c|c|c|c|}
\hline & & 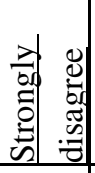 & 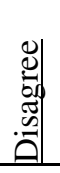 & 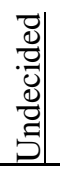 & 递 & 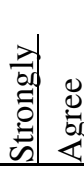 \\
\hline 1. & Inspiration offers opportunities for more effective writing. & & & & & \\
\hline 2. & $\begin{array}{l}\text { Beginning to write in an Inspiration environment is enjoyable and } \\
\text { amusing. }\end{array}$ & & & & & \\
\hline 3. & $\begin{array}{l}\text { In an Inspiration environment, I experience less difficulty organizing } \\
\text { ideas before I write. }\end{array}$ & & & & & \\
\hline 4. & $\begin{array}{l}\text { Planning to write in an Inspiration environment can be managed in a } \\
\text { better way. }\end{array}$ & & & & & \\
\hline 5. & Inspiration enables me to think of more ideas to write about. & & & & & \\
\hline 6. & $\begin{array}{l}\text { I think I am a better writer now that I know how to use computers } \\
\text { (Inspiration) for writing purposes. }\end{array}$ & & & & & \\
\hline 7. & Preparing to write in an Inspiration environment is interesting. & & & & & \\
\hline 8. & Using inspiration helps me avoid ideas which are off the topic. & & & & & \\
\hline 9. & $\begin{array}{l}\text { Graphic aids in Inspiration help me find the relationships among the ideas } \\
\text { that cross my mind. }\end{array}$ & & & & & \\
\hline 10. & $\begin{array}{l}\text { Brainstorming and freewriting are more successful if accompanied by a } \\
\text { software program like Inspiration. }\end{array}$ & & & & & \\
\hline 11. & Inspiration can be useful for any type of writing by any one. & & & & & \\
\hline 12. & $\begin{array}{l}\text { To improve the content of a writing, I suggest everyone should use } \\
\text { Inspiration. }\end{array}$ & & & & & \\
\hline 13. & $\begin{array}{l}\text { Preparing to write in an Inspiration environment creates less anxiety for } \\
\text { me. }\end{array}$ & & & & & \\
\hline 14. & I recommend the use of Inspiration in future writing courses. & & & & & \\
\hline 15. & Overall, I am satisfied with application of Inspiration in writing classes. & & & & & \\
\hline
\end{tabular}


Afshari, S., \& Salehi, H. 